УДК 811. 161.2 ’37

Ю. О. Арешенков

\title{
КОНЦЕПТ НАРОД У ПОЕТИЧНОМУ ДИСКУРСІ «КОБЗАРЯ»
}

Арешенков Ю. О. Концепт НАРОД у поетичному дискурсі «Кобзаря».

Розглядаються особливості маніфестації та функціонування одного з головних концептів мегатексту «Кобзаря». Простежується характер формування ціннісної та експресивно-емотивної складової концептуального змісту.

Ключові слова: концепт, концептосфера, мегатекст, оцінність, атрибутив.

Арешенков Ю. А. Концепт НАРОД в поэтическом дискурсе «Кобзаря».

Рассматриваются особенности манифестации и функционирования одного из главных концептов мегатекста «Кобзаря». Прослеживается характер формирования ценностной и экспрессивно-эмотивной составляющей концептуального содержания.

Ключевые слова: концепт, концептосфера, мегатекст, оценочность, атрибутив.

Areshenkov Y. O. The concept НАРОД (People) in the poetic discourse of «Kobzar».

The features of the manifestation and functioning of one of the main concepts «Kobzar's» MegaText are examined. We investigate the nature of the formation of evaluation and expressive emotive component of conceptual content.

Key words: concept, conceptual, MegaText, evaluation, atributiv.

Поняття Шевченко і народ є органічно й нерозривно пов'язаними. Народність Шевченкової поезії, його художнього світобачення були досліджені в різних аспектах та вимірах. Останнім часом посилилася увага до проблематики, пов'язаної з особливостями поетичного світу Кобзаря на концептуальному рівні. 3 огляду на це виявлення особливостей семантики, засобів вербальної об'єктивізації, характеру композитивних асоціацій концепту НАРОД видається досить продуктивним для подальшого осмислення ментальних глибин Шевченкового слова.

Виявлення ключових слів на площині всього корпусу творів служить плідним орієнтиром у пошуках ідеологічних пріоритетів письменника. Перелік найінтенсивніших ідеотворчих лексем Шевченкової поезії зустрічаємо у грунтовній праці I. Дзюби «Тарас Шевченко. Життя і творчість» (2008). До них, на його думку, належать насамперед такі: ПРАВДА, БОГ, ВОЛЯ, ДОЛЯ, СЛАВА, МАТИ, СІМ'Я, УКРАЇНА, СИРОТА, КОХАННЯ, СМЕРТЬ, ШЛЯХ, НАДІЯ, СОН, СУД, КАРА, МИЛОСЕРДЯ, МУЗА та ін. [1, с. 617].

Завважимо, що в достатньо широкому спектрі наведеної понятійнокатегорійної системи не знайшлося місця для одного з найважливіших як 
універсальних, так і етнокультурних концептів НАРОД. Лексема народ не належить до так званих «улюблених слів» Шевченка у книзі В. Русанівського «У слові - вічність» (2002), хоч синонім люди названо в числі найбільш поширених слів-образів за ознакою прикметникового оточення [2, с. 226].

Слід наголосити на тому, що іменник люди має особливий статус у лексиконі поетичних творів Шевченка. Йому належить абсолютна першість за частотністю вживання серед повнозначних частин мови. У частотному словнику збірки «Тарас Шевченко. Твори в п’яти томах» [3] перша десятка іменників розташована так: люди 276, Бог 266, світ 218, хата 196, серие 185, мати 173, син 166, доля 142, діти 133, земля 128 [числа позначають абсолютну частоту вживання словоформи].

За ступенем функціонального навантаження, тобто в порядку зменшення кількості поставлених відповідно до нього слів-ознак, іменник люди (люде, людина) посідає другу позиції після лексеми діти (дитина, дитя, дитятко, дитяточко) [4, с.13]. Якщо зважити на те, що діти нерідко служить контекстуальним синонімом до слова люди, то питання пріоритетності стає дискусійним. При цьому власне номінатор концепту іменник народ виявляє помітно меншу частотність (15 слововживань) та входить лише до другої сотні списку компонентів атрибутивної конструкції [4, с. 26]. Можна стверджувати, що іменник люди служить для Шевченка основним вербалізатором концепту НАРОД.

3 погляду семантики наявний високий ступінь ідентичності синонімічної пари народ = люди у лексиконі української мови, що, безперечно, знайшло своє вираження в ідіостилі Шевченка. У спеціальних лексикографічних працях (мовокраїнознавчий словник-довідник «Україна в словах» та словник-довідник «Знаки української етнокультури») слово люди фіксується не окремо, а як семантичний компонент концепту НАРОД: «Народ. 1. Населення держави, жителі країни. 2. Взагалі люди, перев. у великій кількості» [5, с. 54]; «Народ = нарід - 1) етнічна та національна єдність людей (етнос, народність, нація); також єдність людей, що проживають у тій чи тій країні незалежно від національності; 2) люди, оточення» [6, с. 386].

Для розуміння концептуальних смислів іменника люди звернімося до характеристики його дистрибуції, зокрема атрибутивного оточення, бо, як уже зазначалося, ця лексема має найвищий коефіцієнт за ступенем сполучуваності з означальними компонентами. Найперше впадає в око активне вживання слів-кваліфікаторів з негативною оцінністю, передусім якісних прикметників як у прямому значенні, так і ускладнених епітетальною конотацією: Дурні та гордіï ми люди (с. 387); О, люде поганий! Де ти взявся? щуо ти робиш? (с. 173); А люд навісний Нехай скаженіє (с. 183); I обличителя жестоких Людей неситих (с. 448); I люде темнії, незрячі Дива господнії побачать (с. 448) [Тут і далі після прикладів зазначаємо номер ๑ Ю. О. Арешенков, 2013. 
сторінки за виданням: Тарас Шевченко. Кобзар. - К. : Дніпро, 1968. - 558 с.].

Схожу картину спостерігаємо і в оточенні інших слів, що слугують репрезентантами концепту НАРОД: За ним $i$ сльози, знай, лили Навчені люди. І лукаві! // I роде лютий і жестокий (с. 331); Схаменіться недолюди, Діти юродиві! (с. 238); А жаль великий на людей, На тих юродивих дітей (с. 322); Тільки ми, Адаме, Твої чада преступниє, не одпочиваєм (с. 429). У небагатьох атрибутивних конструкціях 3 іменником народ теж явно переважають прикметники 3 негативно-оцінною семантикою: божий, вольний :: закований, замучений, темний, убогий, убитий.

Просторові параметри (координати) існування ЛЮДЕЙ головним чином задає концепт СЕЛО. Принагідно зазначимо, що функціонально й семантично близьке до нього слово ХАТА $є$ локалізатором концепту СІМ'Я. Водночас лексема сім'я може бути вербалізатором концепту НАРОД, а концепт ХАТА в Шевченка включає значення «країна», «Україна», «держава».

Художньо-виразний опис життя українського села 3 розгорнутою експлікацією концептів містить поезія «І виріс я на чужині...»: Аж страх погано У тім хорошому селі. Чорніме чорної землі Блукають люди, повсихали Сади зелені, погнили Біленькі хати, повалялись, Стави бур'яном поросли. Село неначе погоріло, Неначе люде подуріли, Німі на панщину ідуть I діточок свойх ведуть!.. (с. 336).

У Т. Шевченка «люди» переважно означають «селяни», сільські люди, люди села. Проте «людське», те, що пов'язане 3 людьми, притаманне їм, аж ніяк не зводиться до «сільське», а може розширюватися до меж «українське» та, як згодом ми побачимо, включати поняття «загальнолюдське, світове»: ...І не в однім отім селі, $A$ скрізь на славній Украйні Людей у ярма запрягли Пани лукаві... (с. 336).

У цьому ж творі поет висловлює свою мрію про можливе щасливе життя, яку образно втілено в метафоричному означенні веселі: Меж горами старий Дніпро, Неначе в молочі дитина, Красується, любується На всю Україну. А понад ним зеленіють Широкії села, А у селах у веселих І люде веселі (с. 337).

Водночас у вірші прямо декларується невідповідність зображуваного конкретній реальності, що полегшує завдання інтерпретації концептуальних смислів: Воно б, може, так і сталось, Якби не осталось Сліду панського в Украйні (с. 337). Описи з експлікацією позитивних оцінних значень зустрічаємо також у творах, що містять спогади про недавнє минуле особистого життя (вірш «Г. З.») або мрії про власне майбуття («Лічу в неволі дні і ночі...»): I передо мною Ніби море заступають Широкії села 3 вишневими садочками I люде веселі. I ті люде, і село те, Де колись, мов брата, Привітали мене (с. 322); Бо немає в мене роду На всій Україні, Та все-таки не ті люде, Що на иій чужині! Гуляв би я понад Дніпром По веселих селах Та співав би свої думи, Тихі, невеселі (с. 392). 
Творам, де йдеться про реальну дійсність, притаманна критична характеристика (переважно морально-етичних якостей) людей у діапазоні від стриманого нарікання до гостро сатиричного засудження, напр.: Мій Боже милий, як то мало Святих людей на світі стало (с. 447); О люди! люди небораки! (с. 500); Свої люде - як чужї̈, Ні з ким говорити... (с. 20); Кругом мене, де не гляну, Не люди, а змії... (с. 254). Негативна оцінка всього підлого, того, що не гідне звання людського, досягає виняткового ступеня у відверто декларативних рядках поезії «П. С.» (Не жаль на злого...): Люде, люде! За имат гнилої ковбаси У вас хоч матір попроси, То оддасте. Не жаль на його, На п'яного Петра кривого. А жаль великий на людей, На тих юродивих дімей! (с. 322).

Статистичні обрахунки засвідчують стабільну перевагу експліцитно та імпліцитно виражених негативних смислів у семантичному полі Шевченкового концепту НАРОД. Між тим, дискурсивний аналіз дав змогу виявити ряд інтерпретаційно важливих контекстів, де простежується зміна оцінного полюсу. Ціннісний компонент концепту НАРОД набуває окреслено позитивного значення, потрапляючи в поле контекстуальноасоціативних зв'язків 3 концептом БОГ: Господь любить свої люди, Любить, не оставить... (249); Добро тварям земнородним, I землі, $i$ людям, - Отак братів благих своїх Господь не забуде, Вочариться в дому тихих, В сем'ї тій великій... (250); I світ Божий як Великдень, I люди як люди! (21); Ходімо в селища, там люде, А там, де люде, добре буде. Там будем жить, людей любить, Святого Господа хвалить (315).

У Шевченковому світі Бог - єдиний і незаперечний авторитет: Не хрестись, I не кленись, і не молись Нікому в світі! Збрешуть люде, I візантійський Саваоф Одурить! Не одурить Бог, Карать і миловать не буде: Ми не раби Його - ми люде! (с. 494).

Поетове трактування Абсолюта та вищих цінностей, як відзначалося багатьма дослідниками, посутньо відрізняється від церковно-догматичного, але й не зводиться до гуманітарно-просвітницького. Віра в себе і віра в Бога дає людям сили здолати зло, «поховать лихе дебеле» (с. 494). Лихо людям чинять «нелюди» (недолюди, розбійники, людоїди, «змї̈»...), і подолати ворожу силу можна, благаючи Бога і сподіваючись Божого ласки: «Cnacu $\boldsymbol{T u}$ нас, святая сило... Не дай згнущатися лукавим I над Твоєю вічно-славой, Й над нами, простими людьми!..» (с. 190); Радуйтеся, вбогодухі, Не лякайтесь дива, - Се Бог судить, визволяє Долготерпеливих Вас, убогих. I воздає Злодіям за злая! (с. 448).

Важливо назвати ще ряд концептуалізованих лексем, які суттєво впливають на семантичне поле слова народ (люди). Це насамперед іменники правда / неправда, воля / неволя та їх синоніми. У художньому світі «Кобзаря» ці слова набувають статусу соціально-політичної категорії: наявність ПРАВДИ, ВОЛІ сприймається як запорука щасливого життя (๑) Ю. О. Арешенков, 2013. 
НАРОДУ: Кругом неправда $і$ неволя, Народ замучений мовчить (с. 188); Чи буде суд! Чи буде кара! Царям, царятам на землі? Чи буде правда меж людьми? (с. 500); Де нема святої волі, Не буде там добра ніколи (с. 314).

Повернути ПРАВДУ, здобути ВОЛЮ люди зможуть з Божої ласки, 3 Божою допомогою: Колись Бог нам верне волю. Розіб' $є$ неволю (с. 247). Щасливе життя, щасливі люди - заповітне бажання, яке може бути зреалізоване за умови докорінних історичних змін («оновлення»), коли в людській спільноті не буде панів, ворогів, лиходіїв, супостатів: I на оновленій землі Врага не буде, супостата, А буде син, і буде мати, I будуть люде на землі (с. 495).

Індукований оптимізм загальної ідейно-художньої перспективи Шевченкової поезії вносить певну амбівалентність у достатньо потужне поле негативних конотацій навколо смислового ядра концептуальної структури. Вертикальна взаємодія лексем (смислів), що виявляють контекстуально-асоціативні зв'язки 3 концептом НАРОД, породжує виразну когнітивно-образну схему, яка значною мірою представляє концептуальний зміст усього мегатексту «Кобзаря»: А) поневолений люд (раби, сірома, невольники...) - В) уярмлено недолюдами (розбійниками, людоїдами, лиходіями, супостатами...) - С) яких вони з Богом здолають і назвуться людьми («і будуть люде на землі»).

Концепт НАРОД є одним із провідних у концептосфері «Кобзаря», маніфестуючись у низці творів різних за жанром та тематикою.

Основним репрезентантом концептуального значення «оточення» та «населення» $є$ іменник люди. Іменники нація та украӥнці, як найбільш очевидні 3 погляду сучасності репрезентанти концепту НАРОД, у словнику поетичної мови Т. Шевченка відсутні.

В атрибутивних конструкціях із словами-номінаторами концепту переважають поширювачі з негативно-оцінною семантикою. Ціннісну та емотивно-експресивну складову створюють також дисфемізми, що у своїй сукупності формують антонімічне значення «нелюди».

Ціннісний компонент концепту НАРОД набуває окреслено позитивного значення, потрапляючи в поле контекстуально-асоціативних зв'язків з концептом БОГ.

Вертикальна взаємодія концептуальних смислів утворює сталі лексико-семантичні біноми село - люди; країна - народ. У подальшому можна простежити їхні контекстуальні та асоціативні зв'язки з концептами СIM'Я, ХАТА, що дасть змогу більш глибоко розкрити роль функціонально-семантичної взаємодії концептуалізованих слів у формуванні ідейно-естетичного змісту літературного твору.

\section{Література}

1. Дзюба I. М. Тарас Шевченко. Життя і творчість / I. М. Дзюба. - [2-ге вид.]. - К. : Вид. дім «Києво-Могилянська академія», 2008. -718 с. 
2. Русанівський В. С. У слові - вічність : (Мова творів Т. Г. Шевченка) / В. С. Русанівський. - К. : Наук. думка, 2002. - 240 с.

3. Частотний словник збірки «Твори в п'яти томах». Тарас Шевченко / Режим доступу : http://www.mova.info/cfq.aspx?fdid=shev4

4. Меншиков I. I. Поетичне слово Кобзаря : Словник лексичних компонентів атрибутивних конструкцій / I. І. Меншиков, Н. В. Підмогильна. - Дніпропетровськ : Січ, 1991. - 206 с.

5. Україна в словах : Мовокраїнознавчий словник-довідник / [Упоряд. і кер. авт. кол. Е. Данилюк]. - К. : ВЦ «Просвіта», 2004. - 704 с.

6. Жайворонок В. В. Знаки української етнокультури : [словник-довідник] / В. В. Жайворонок. - К. : Довіра, 2006. - 703 с. 